\title{
THE VARIETY OF ECOLOGICAL PROBLEMS IN CRIMEA REPUBLIC AND ITS DAMAGE ASSESSMENT
}

\author{
(c) Yulia A. Petrova, Anastasia A. Lebesheva \\ Rostov State University of Economics. Rostov-on-Don, Russian Federation \\ science-almanac@mail.ru
}

\begin{abstract}
The level of human impact on the environment depends greatly on the technical equipment of the society. It was extremely small at the initial stages of human development. However, with the development of society and the growth of its productive forces, the situation begins to change dramatically. The twentieth century is an age of scientific and technological progress. Connected with a qualitatively new relationship of science and technology, it enormously increases possible and real scale of the impact of society on nature, posing a whole series of new, extremely acute problems for humanity, first of all - ecological. In our article we find out an enumeration of ecological problems, which appeared from over gradual civilizational development, on Crimean Peninsula and we also analyze the extent of the caused damage. In conclusion we would like to mention that drastic and radical measures should be taken for stabilizing the environmental situation, in other case we will simply lose this unique region.
\end{abstract}

Key words: Crimean Peninsula, environmental situation, ecological problems, society.

\section{[Ю.А. Петрова, А.А. Лебешева Разнообразие экологических проблем в Крымской республике и оценка ущерба]}

Уровень воздействия человека на окружающую среду во многом зависит от технического оснащения общества. Что было крайне мало на начальных этапах развития человека. Однако с развитием общества и ростом его производительных сил ситуация начинает резко меняться. Двадцатый век - это век научно-технического прогресса. Связанный с качественно новым отношением науки и техники, что чрезвычайно увеличивает возможный и реальный масштаб воздействия общества на природу, представляя целый ряд новых, чрезвычайно острых проблем для человечества, прежде всего - экологических. В нашей статье мы исследуем перечень экологических проблем, возникших из-за постепенного цивилизационного развития на Крымском полуострове, а также проанализируем степень причиненного ущерба. В заключение хотелось бы отметить, что для стабилизации экологической ситуации необходимо принять решительные и радикальные меры, в противном случае мы просто потеряем этот уникальный регион. щество

Ключевые слова: Крымский полуостров, экологическая ситуация, экологические проблемы, об-

Yulia A. Petrova - candidate of philosophy, associate professor. Rostov state university of economics. Rostovon-Don, Russian Federation.

Anastasia A. Lebesheva - Rostov state university of economics. Rostov-on-Don, Russian Federation.

Петрова Юлия Андреевна - кандидат фрилософрских наук, доцент. Ростовский государственный экономический университет. Ростов-на-Дону, Россия.

Лебешева Анастасия Алексеевна - Ростовский государственный экономический университет. Ростов-на-Дону, Россия.

The processes of degradation of the surrounding environment are caused by the negative social practices based on the consumer society values, characterized by the low level of ecological culture, lack of exhaustive ecological information. All this causes the crisis phenomena, decline in quality of life and deterioration in human health, mismatch of economics, social, cultural and ecological interests of various social groups. These signs can be found in political, legal, economic, social, information, educational and other spheres of society. Nowadays there is a need for change in the sphere of society, it is caused by the 
need for a person and society of adaptation to the future and need of creation within the space of culture, educational space, positive social ecological practices, their use in everyday life of each person and society in general.

The relevance of the article is determined by the fact that human only treats nature as a consumer, receiving profit from it, and gives nothing in return. In our article we find out an enumeration of ecological problems, which appeared from over gradual civilizational development, on Crimean Peninsula and to analyze the extent of the caused damage.

Crimea covers an area of 27000 square kilometers, in other words, it is $0,02 \%$ of the Earth land and about $0,3 \%$ of Europa's territory. The Crimean peninsula is deeply exposed to the Black Sea, which washes it from the south and west, from the east it is washed by the Azov Sea and Lake Sivash. In the north it connects the continent with a narrow (up to $8 \mathrm{~km}$ ) Perekop Isthmus. The relief of the Crimean peninsula is represented by three unequal parts: the North Crimean plain with the Tarkhankut Upland (about $70 \%$ of the territory), the Kerch Peninsula and the mountainous Crimea stretching three ridges in the south. The length of the coastal strip of the Crimean peninsula is $1500 \mathrm{~km}$. The area of the peninsula divides on the following parts: $72 \%$ is plain, $20 \%$ are mountains and $8 \%$ are lakes, rivers and other water objects. The large amount of nature conditions and landscapes, which are bound by its geographical location and geomorphological structure, characterize the Crimean Peninsula. Long anthropogenic influence lead to deterioration of many natural anthropogenic landscapes and formation of the new ones, therefore exists its diversity. Nowadays natural tenuously intact landscapes occupy about $2.5 \%$ of Crimean territory. This small part consists of mountain broadleaved forests, wooded steppes on mountain pastures, alkaline earth and meadows of Sivash gulf area and Kerch Peninsula. The most part (62\%) includes useful landscapes such as ploughed lands, gardens, cities, roads, etc. The rest one $(35,5 \%)$ is epigenetic landscapes.

Crimea has unique landscapes and nature, but because of people's activity the ecology of the peninsula suffers and receives great harm: air, water, land is polluted, biodiversity, ranges of flora and fauna are reduced. A fairly large part of the Crimean peninsula is occupied by steppes, but in the course of their economic development more and more territories are being used for agricultural lands and pastures for cattle. All this leads to the following consequences: salinity of the soil, erosion of soil, decrease in fertility $[1 ; 8]$.

The creation of a system of water canals facilitated the change of water canals. Some areas began to get excess moisture, therefore there is a process of bogging the earth. Crimea belongs to regions with extremely difficult conditions for water supply, own water sources can meet the demand only by $28 \%$. At the same time, 100 underground water intakes show increased mineralization, exceeding the GOST by 3-4 times (Razdolnensky, Chernomorsky, Saksky and other regions), which is a risk factor for developing cholelithiasis and urolithiasis in the population. In many areas of the Crimea, significant pollution of groundwater with nitrogenous compounds, including nitrates, is associated with a large use of fertilizers in agriculture, as well as organic soil contamination. Also the use of pesticides and agrochemicals that pollute the soil and groundwater affects the soil condition. Significant impact on the natural environment occurred with the introduction of the North Crimean Canal. The area of irrigated land in the Crimea reached about $20 \%$ of all cultivated land. However, due to the poor technical condition of the canal, about half of the water is lost, and this caused an increase in the level of groundwater, flooding of lands, salinization of the soil. Irrigation led to a qualitative change in landscapes: rice fields appeared, the area of gardens, vegetable and tilled crops increased. There were new settlements, the population of agricultural areas has grown. Crimea is washed by the Azov and Black seas. These water areas also have a number of environmental problems: water pollution by oil products, eutrophication of water, reduction of species diversity, dumping of domestic and industrial debris in water, in reservoirs appear alien species of flora and fauna. It is worth to note that 
the coast is heavily overloaded with tourist and infrastructure facilities, which gradually leads to the destruction of the coast. Also people do not observe ecological rules while exploring a sea, exhaust the ecosystem and sometimes emergencies of different nature happen. Talking more detailed, water content evaluation of the of biogenic matters and dissolved oxygen gives an idea of the internal biotransformation of organic substances in marine ecosystems, and therefore hydrochemical studies of the southern seas are relevant, their main goal is to control water quality, restore or maintain the productivity of the seas, realization of their ecosystems management. During the complex expeditions of the Southern scientific centre RAS in 2007-2008, in littoral (from Kerch Strait to Adler) and the outshore part of Black sea at SRS "Deneb" the water samples were selected and analyzed directly on the board, where the water temperature, active $(\mathrm{pH})$ reaction, dissolved oxygen concentration, nitrites content, nitrates, phosphates were determined. In 2008, special attention was paid to the quality of the Kerch Strait waters in connection with the ship crash that occurred on November 11, 2007.

As well as in different parts of the world, in Crimea there is a huge problem of solid household waste and garbage, as well as industrial waste and dirty sewage. 10.6 million tons of toxic wastes have been accumulated in the territory of Crimea, including 866.9 tons of unsuitable, banned and unidentified pesticides. In Crimea there are 28 officially registered landfills of solid domestic waste, where 18.3 million tons of waste are accumulated. Most of the landfills have exhausted their sanitary and technical and territorial capabilities. This problem has not been solved for many years due to the lack of financing and the lack of free land. Everybody litters here: both the inhabitants of cities and tourists. Virtually no one worries about the purity of nature. But the garbage, falling into the water, bears death to the animals. Abandoned plastic, polyethylene, glass, diapers and other wastes are recycled in nature for hundreds of years. Thus, soon the resort will turn into a big dump [3].

Many species of wild animals live in the Crimea, and some of them are rare and listed in the Red Book. Unfortunately, poachers hunt them for profit. This reduces the populations of animals and birds, while illegal hunters catch and kill animals at any time of the year, even when they bring offspring. Zoologist Alexandra Savchuk told about the state of the wild world in Crimea. According to her words, all three species of dolphins that exist near the coast of the peninsula are listed in the Red Book. Because of human activity, their population decreases every year, they fall into the network of poachers. The number of fish suitable for food is decreasing. The next species, representing the wildlife of the Crimea, is so rare that few people could have thought of his living on the peninsula. This seal is a monk belobruchy. Meeting him in the Black Sea near the coast of the republic - a great success. According to the "Red Book" of Crimea, near the coast of the peninsula, the species was completely destroyed by man in the 1920s. However, from time to time information that fishermen have seen a monk seal appears [8].

The Red Book includes 47 species of plants that grow on the peninsula. The abundance of endangered species testifies to the threatening situation in which they found themselves because of the high recreational load on the local territories.

A characteristic feature of the Crimean landscapes is the neighboring growth of Central European plants with representatives of the flora from the Near East. Some relic plants that existed before the arrival of the glacier were preserved here: the Comperia orchid, the tall juniper, and the small-fruited strawberry. 142 species of plants on the peninsula are considered endemic, since they are nowhere else to be found.

The issues of preservation of the environment and improvement of the ecological situation in the Black Sea region occupy an important place in the concept of its development. Today, the issues of improving the environmental situation, sustainable development, reducing the consumption of natural resources, and increasing the energy efficiency of the economy are formulated as priority tasks of the state. The key to the successful implemen- 
tation of the concept of sustainable development of Crimea is the population's awareness of the severity of environmental problems, which is achieved through environmental education and education, general awareness, and promotion of a healthy lifestyle.

Any solution to global planetary issues, all the more related to the life activity of civilization and the biosphere, must be based on worldview principles. Only on the basis of the logic of development of the biosphere and society as an integral part of the biosphere and its nature, mankind has the right to assess the current ecological situation and formulate plans for its operation. The ideological foundations, ultimately, should determine the idea and meaning of the human society action, although the process of the world outlook forming (and the formation of the corresponding consciousness) is extremely complex and subject to many factors of the social plane, such as lifestyle and customs, relationships with different people, the nature of ecosystems [2]. In the search for new solutions to the development of the sphere of reason and the harmonic interactions of nature and society, the cognitive power of science plays a crucial role at the present time [7].

As a result, we observed that the unregulated use of the Crimea continued throughout most of its history, which led to serious environmental problems. Crimea today is a specific region, where a large number of rare species of animals and plants, unique climatic zones and ecological reserves are concentrated. Unless drastic and radical measures are taken to stabilize the environmental situation, we will simply lose this unique region [5]. The government of both Russia and the Crimea should pay more attention to this issue, toughening environmental policy and applying more severe sanctions to violators of environmental legislation. Nowadays the global nature of environmental problems requires a different way of thinking from man, a new form of awareness - ecological consciousness. This means that a person must realize himself as a whole in his relationship to nature. The first and main condition of maintaining the balance and harmony with nature is the reasonable coexistence of people with each other. It is necessary to combine the efforts of all people, of all mankind in the solutions of these problems.

\section{Лumepamypa}

1. Багров Н.В., Бокова В.А. Экология Крыма. Симферополь, 2003.

2. Камалова О.Н., Склярова Е.К. Историко-медицинские музеи Ростовского государственного медицинского университета // История медицины в собраниях архивов, библиотек и музеев / материалы III Межрегиональной научно-практической конференции. 2016.

3. Подгородецкий П.Д. Крым: Природа. Таврия, 1988.

4. http://82.rpn.gov.ru/ecoinfa РОСПРИРОДНАДЗОР.

5. Basilaia M.A., Zharkova M.G. Search for new ways of ecological crisis overcoming // Научный альманах стран Причерноморья. 2017. № 2.

6. Kolosova O.Y., Goncharov V.N. Positive ecological practices formation as condition for ecological crisis overcoming // Научный альманах стран Причерноморья. 2017. № 2.

7. Petrova Yu., Yarovoy M. Comparative-historical and cultural analysis of eastern Black sea region people's interaction // Научный альманах стран Причерноморья. 2017. № $3(11)$.

8. Filatova T.V. Expedition hydrochemical studies of the Black Sea coastal zones and the Kerch Strait in 2007-2008 // Научный альманах стран Причерноморья. 2017. № 3.

References

1. Bagrov N.W., Bokova V.A. Ecology of the Crimea. Simferopol, 2003. 
2. Kamalova O.N., Sklyarova E.K. Historical medical museums of the Rostov State Medical University // History of medicine in collections of archives, libraries and museums; Materials of the III Interregional Scientific and Practical Conference. Volgograd, 2016.

3. Podgorodetskiy P.D. Crimea: Nature. Tavria, 1988.

4. http://82.rpn.gov.ru/ecoinfa ROSPRIRODNADZOR

5. Basilaia M.A., Zharkova M.G. Search for new ways of ecological crisis overcoming // Science almanac of the Black Sea region countries. 2017. No 2.

6. Kolosova O.Y., Goncharov V.N. Positive ecological practices formation as condition for ecological crisis overcoming // Science almanac of the Black Sea region countries. 2017. No 2.

7. Petrova Yu., Yarovoy M. Comparative-historical and cultural analysis of eastern Black sea region people's interaction // Science almanac of the Black Sea region countries. 2017. № 3 (11).

8. Filatova T.V. Expedition hydrochemical studies of the Black Sea coastal zones and the Kerch Strait in 2007-2008 // Science almanac of the Black Sea region countries. 2017. No 3. 